\title{
A.14 University of Tokyo Library, Ms. $419^{29}$
}

A Nepalese paper manuscript of 312 leaves from 1792 CE (NS 912). ${ }^{30}$ There are two additional folios with a numbered list of 158 dhāranīs. ${ }^{31}$

1. Saptaśatikā-prajñāpāramitā 39v [163]

2. Abhisamayālaṃkāra-nāma-prajñāpāramitopadeśaśāstra 55v

3. Prajñāpāramitā-dhāraṇī $55 v[8,56]$

4. Pìtavarṇa-prajñāpāramitā-dhāraṇī 56v [55,162]

5. Prajñāpāramitā-dhāraṇi 56v [8,56]

6. S Ṣaṭpāramitā-hṛdaya-nāma-dhāraṇī 57v [59]

7. Vairocanī-nāma-dhāranī $57 \mathrm{v}$ [3]

8. Akșobhya-nāma-dhāraṇī 58r [4]

9. Ratnasambhava-nāma-dhāraṇī 58r [5]

10. Amitābha-nāma-dhāraṇī 58r [6]

11. Amoghasiddhi-nāma-dhāraṇī 58v [7]

12. Durgatipariśodhanī-nāma-dhāraṇī $58 \mathrm{v}$ [45,74]

13. Śākyamunīnām viśeṣa-dhāraṇī 59r [35]

14. Sarvajñatāmukhapraveśa-nāma-dhāraṇī 65v [53]

15. Nāmasaṃīiti-dhāraṇi 66r [57,115]

16. Aparimitāyur-nāma-dhāraṇī 76v [47]

17. Pañcavimịśatikā-prajñāpāramitā-nāma-dhāraṇī 78r [101]

18. Pītavarṇa-prajñāpāramitā-dhāraṇī 78v [55,162]

19. Gaṇụavyūha-nāma-dhāraṇī 78v [9]

20. Sarvabodhisattvacaryāprasthāna-daśabhūmīśvara-nāma-mahāyānasūtraratnarāja 83v [10]

21. Samādhirāja-nāma-dhāranịi 83v [11]

22. Lañkāvatāra-nāma-dhāraṇī 85r [12]

23. Saddharmapuṇụarīkāyā mantra-dhāraṇī 86r [13]

24. Tathāgataguhya-nāma-dhāraṇī 88v [14]

29 Available online: http://picservice.ioc.u-tokyo.ac.jp/03_150219 UT-library_sanskrit_ms/MF13 _50_004 MF13_50_004/?pageId=001 (accessed March 2020). Titles given with minor standardizations. Corresponding text numbers in Cambridge Ms. Add. 1326 are given in square brackets (there is a chance of inconsistencies in the case of texts which appear by the same title more than once). 30 Matsunami 1965: 149. The mostly illegible dated colophon is on folio 312.

31 Note that this list that looks like a table of contents only at places corresponds to the sequence of texts in the actual manuscript. The numbering of the 158 dhāranīs is inconsistent on these two folios. 
25. Bhagavān-lalitavistare trapuṣabhallikaparivartanāya-bhāṣitakalyāṇavākya 91r [15]

26. Suvarṇaprabhāsottamasūtrendrarāje sarvabuddhabodhisattva-nāma-saṃdhāraṇī-parivarta 91v [16]

27. Amoghapāśa-nāma-hṛdaya-mahāyānasūtra 101v [63]

28. Maitreyapratijñā-nāma-dhāraṇī 102v [87]

29. Mañjughoṣakṛti-praṇidhānarāja 103r [88]

30. Sahasrabhujalokeśvara-dhāraṇī 103r [66]

31. Siṃhanādalokeśvarasya vyādhipraśamaṇī-dhāraṇī 103v [64]

32. Avalokiteśvarasya mukhodgīrṇa-siddhinikā-nāma-dhāraṇī 104r [65,116]

33. Avalokiteśvarasya nīlakaṇthha-nāma-dhāraṇī 105v [67]

34. Sahasrāvarta-nāma-dhāraṇī 106r [68]

35. Șaḍakṣarī-mahāvidyā-nāma-dhāraṇī 107v [69]

36. Bhadracari-mahāpraṇidhānarāja 112r [70]

37. Mokșapada-nāma-dhāraṇī 112r [71]

38. Abhayaṃkarī-nāma-dhāraṇī 113r [72]

39. Maṇibhadra-nāma-dhāraṇī 113v [73]

40. Vajrapāṇi-mahārakṣā-nāma-dhāraṇī 114r [49]

41. Herukasya sarvarogapraśamanī-nāma-dhāraṇī 114v [144]

42. Cundābhagavatī-dhāraṇī 114v [75]

43. Hutāśanatejo-nāma-dhāraṇi 115r [37]

44. Bhaiṣajya-nāma-dhāraṇī 115r [38]

45. Mañjuśrīpratijñā-nāma-dhāraṇī 115r [58]

46. Padmahasta-nāma-dhāraṇī 115v [17]

47. Mañgala-nāma-dhāraṇī 115v [39]

48. Karṇajāpā-nāma-dhāraṇī 115v [40]

49. Sarvapāpadahanī-nāma-dhāraṇī 116r [41]

50. Yakṣāṣțaka-samyaksambuddhabhāṣita 116v [60]

51. Jambhalajalendrasya-nāma-dhāraṇī 117v [61]

52. Vasudhārā-nāma-dhāraṇī 136r [62,82]

53. Vasudhārā-nāma-dhāraṇī 137r [62,82]

54. Mahāpratisarā-mahāvidyā-dhāraṇi 144v [76]

55. Pratisarākalpa-dhāraṇi 147v [77]

56. Mahāsāhasrapramardanī-nāma-vidyā-dhāraṇi 163v [78]

57. Mahāmāyūrì-vidyārājñī-nāma-dhāraṇī 181v [79]

58. Mahāŝîtavatī-nāma-vidyā-dhāraṇī 184v [80]

59. Mahāmantrānusāriṇī-mahāvidyā-nāma-dhāraṇī 188r [81]

60. Sarvatathāgatoṣnīṣasitātapatra-nāmāparāitā-pratyañgirā-mahāvidyārājñī 198v [83]

61. Mūlavidyā-nāma-dhāraṇī 199r [1] 
62. Śatākṣara-nāma-dhāraṇī 199v [2]

63. Sapane(pavane ms.)-vidyā-dhāraṇī 200r [84]

64. Jātismara-nāma-dhāraṇī 200r [36]

65. Jātismara-nāma-dhāraṇī 200v [36]

66. Parṇaśavarī-mahāmārīpraśamanī-nāma-dhāraṇī 201v [85]

67. Hemāñgā-nāma-dhāraṇī 202v [86]

68. Mahāvidyārājasamādhivajraguhyottara-paramatantra-yantra-mantraaprameyaphala 203r

69. Tārāpratijñā-nāma-dhāraṇī 203v [89]

70. Dhvajāgrakeyūra-nāma-dhāraṇī 205v [90]

71. Gāthādvaya-nāma-dhāraṇī 206v [43]

72. Ṣạ̣mukhī-nāma-dhāraṇī 206v [44]

73. Mahāmāyāvijayavāhinī-nāma-dhāraṇī 209v [91]

74. Sāhyambhuvihārāmnāya-varṣāpaṇa-vidhi 215r

75. Bhaviṣyapurāṇe saptamīkalpe bhagavataḥ śrīsūryasya nāmnā sahasrasampūrṇa 223v

76. Kurukullā-nāma-dhāraṇī 224r [95]

77. Jāngulì-nāma-dhāraṇī 224v

78. Mārīcī-nāma-dhāraṇī 225r [92]

79. Vajrasarasvatī-sādhana 225v [93]

80. Vajravairocanī-stava 226r [96]

81. Ușṇīṣacakravartī-nāma-dhāraṇī 226r [50]

82. Vajravidāraṇa-hṛdaya-mantra-nāma-dhāraṇī 228r [98]

83. Gaṇapati-hṛdaya-nāma-dhāraṇī 229v [99]

84. Uș̣ị̄ṣavijayā-nāma-dhāraṇī 231v [100]

85. Mārīcī-nāma-dhāraṇī 233r [102]

86. Grahamātṛkā-nāma-dhāraṇī 234v [103]

87. Hayagrīvakalpe vajragandhā-nāma-dhāraṇī 235r [104]

88. Mahāmāyāvajravārāhī-nāma-dhāraṇī 237r [105]

89. Mahābhairavasya-nāma-dhāraṇī 238r [108]

90. Cintāmaṇi-nāma-dhāraṇī 239r [33,109]

91. Cintāmaṇi-nāma-dhāraṇī 239r [33,109]

92. Cundābhațțārikāyā rakșāmantra 239v [110]

93. Ekajaṭīnāma-dhāraṇī 243v [113]

94. Grahamātṛkā-nāma-dhāraṇī 250r [177]

95. Daśakroḍhamahābhairavāṇāṃ-nāma-dhāraṇī 250r [114]

96. Āryāvalokiteśvarasya mukhodgīrnā-siddhinikā-nāma-dhāraṇī 251r [116]

97. Amṛtabhakṣā-nāma-dhāraṇī 251r [117]

98. Așțamahābhayaharaṇatārā-nāma-dhāraṇī 251v [118]

99. Buddhabhaț̣ārakasya dhāraṇī 251v [119] 
100. Yogāmbarasya karmarāja-nāma-dhāraṇī 252r [120]

101. Sarvalokeśvara-dhāranī 252r [121]

102. Khasarpaṇa-nāma-dhāraṇī 252r [122]

103. Arapacanamañjuśrīināma-dhāraṇī 252v [123]

104. Maitreya-nāma-dhāraṇī 252v [124]

105. Saddharmapātha-dhāraṇi 252v [125]

106. Vajratārā-nāma-dhāraṇī 253r [126]

107. Ugratārā-nāma-dhāraṇī 253r [127]

108. Daśakrodhānāṃ dhāraṇī 253v [128]

109. Lokapālasya nāmānāṃ dhāraṇī 253v [129]

110. Gaganākșepavajrayoginī-nāma-dhāraṇī 254r [130]

111. Raktayamāri-nāma-dhāraṇi $254 \mathrm{v}$ [131]

112. Prasannatārā-nāma-dhāraṇī 254v [132]

113. Mahābhairavasya dhāraṇī $254 \mathrm{v}$ [133]

114. Siddhivighneśvara-dhāraṇī 255r [134]

115. Mahākālasya dhāraṇi 255r [135]

116. Gaṇeśasya șoḍaśa-nāma 255v [136]

117. Vasudhāraṇy-upadeśa 255v [137]

118. Mañjūśrīibhaț̣āakakasya pratijñā-nāma-dhāraṇī 256r [58]

119. Puṇyavivardhana-nāma-dhāraṇī 256v [138]

120. Șaḍakșarī-dhāraṇī 258r [139]

121. Sarvajñajinadhāturatnakaraṇụaka-nāma bhagavata āryāvalokiteśvara-stotra 260v [140]

122. Vajragāndhārī-nāma-dhāraṇī 261r [141]

123. Kālacakre nibaddha-dhāraṇi 261v [142]

124. Hevajradhāraṇapūjā-vidhi-saṃgraha 263r [143]

125. Mahāsarasvatī-dhāraṇī 264r [94]

126. Mahāpratisarā-dhāraṇi 264v [145]

127. Mahāpratisarāyā sādhana 265v [146]

128. Mahāmāyūrī-dhāraṇī 266r [147]

129. Mahāsāhasrapramardanī-sādhana 266r [148]

130. Mantrānusāranīi-sādhana 266v [149]

131. Mahāśîtavatī-sādhana-nāma-dhāraṇī 266v [150]

132. Pañcarakṣā-mahādevyā sādhana 272v [151]

133. Hastapūjā-vidhāna 273v [152]

134. Nairātmā-sādhana-dhāraṇī $274 r$ [153]

135. Vajrahūṃkārabhairavasya dhāraṇi $274 r$ [154]

136. Hayagrīva-dhāraṇi 274v [155]

137. Hayagrīvabhairavasya dhāraṇī 275v [156]

138. Bhūtaḍāmara saṃkṣipta-dhāraṇī 276v [157] 
139. Gagaṇātmajaśuklavarṇavajravārāhī-nāma-dhāraṇī 278r [158]

140. Vajrayoginī-nāma-dhāraṇi 278v [159]

141. Vajraśrn̉khalā-dhāraṇī 279v [160]

142. Saṃkṣipta-dvibhujaherukasya-nāma-dhāraṇi 280v [161]

143. Vasudhārā-dhāraṇi 281r [165]

144. Sitātapatrāparājitā-nāma-dhāraṇī 281v [166]

145. Vajracarcikā-nāma-dhāraṇi 282r [167]

146. Dhvajāgrakeyūrā-sādhana-dhāraṇī 283v [168]

147. Ușnịịavijayā-sādhana-dhāraṇī 285r [169]

148. Mahāmāyā-nāma-dhāraṇī 286r [170]

149. Vajrajvālānalārka-dhāraṇi 286v [171]

150. Caṇḍamahāroșaṇa-dhāraṇī 287r [172]

151. Mahāsaṃvarasya karmarājaviśuddhi-nāma-dhāraṇī 288v [173]

152. Hevajra-nāma-dhāraṇī 289r [174]

153. Svalpākṣarā-bhagavatī-prajñāpāramitā 292r [164]

154. Trailokyavijayā-nāma-dhāraṇi 292v [175]

155. Lokātīta-stava $294 \mathrm{r}$ [176]

156. Pìthā-stava-stotra 298v [178]

157. Skaṇḍapūrāne śanaiścara-stava 301v [180]

158. Sarvajñatākāra-dhāraṇī 312r [53] 